告であった. 縮小率の大きいIP は, 縮小によりウィナー スペクトルは良くなるが, 微小信号像も縮小されるため に検出能が小さくなるのではないかとの報告であった。

この演題群ではスクリーン・フィルムシステムを基準 にして, CR の検出能, および空間周波数特性の比較研究 であった。デジタル画像では，どうしてもその画像を構 成している最小単位のピクセルあるいは画素に，情報が 平均化される．これはデジタル化による免れないことで ある.しかし，デジタル化することによってさまざまな 画像処理が可能となり，診断に役にたつよりよい情報を 抽出することができるのではないかと思う. そのために は CR に限らずシステムの持つ基本特性，あるいは性能 を十分に把握する必要がある，ここでは，その基礎研究 を発表していただいたわけであるが，今後，この研究成 果を臨床において活用され，よりよい CRイメージを作 り上げていただき，その成果に期待したい.

CR-3 画像処理（演題番号124～128）

阿南充洋（国立がんセンター）

演題124 同一被写体を撮影しても, 使用する IP のサ イズによりでき上った画像に差がある。四ツ切と六ツ切 を比較すると, 六ツ切の方がネムイ画像となる，この六 ツ切画像を四ツ切画像と同程度の画像とするには, 周波 数ランクで 2 段階程度高周波側に，また階調を約 $20 \%$ 立 てる必要がある。

質問（座長） IP サイズを小さくすると収録ラチチ ュードは狭くなり, 高コントラストの画像となるはずで あるが，そのことを加味してもネムクなるのか？

答（芳賀）そのとおりである，ただし，本実験は固 定ラチチュードで収録した。

質問 (座長) どの部位でそうなるのか？

答（芳賀）四肢骨が顕著である.

座長の経験では，撮影部位により，逆（IPサイズを小 さくするとコントラストが高くなる）のこともあるので， auto モードで行うのは大変難しいことと思われるが, 演 者が述べているように「IP サイズごとに，個別の画像処 理をしなければならない」ものと思われる。

演題125 撮影管電圧と識別能との関係について検討 したものである。結論としては, 低圧の方が識別能が高 い.また，階調処理により，コントラストを高くしても， 見易くはなるが識別能に大きな差はなかったということ である。

演題126 grid法による乳房撮影において, screenfilm 系 (single $\mathrm{S} / \mathrm{F}$ 系， double $\mathrm{S} / \mathrm{F}$ 系）とCR との視覚
的な識別能をファントムを用いて検討したものである. 結論としては，CRでは，それぞれの $\mathrm{S} / \mathrm{F}$ 系の約半分の 線量で, それぞれの $\mathrm{S} / \mathrm{F}$ 系と同程度の画像が得られると のことである.

演題127乳房撮影における石灰化像について, 収録ラ チチュードと視覚的識別能との関係をファントムを用い て検討したものである，石灰化像の存在認識には，狭い ラチチュード $(\mathrm{L}=0.8 \sim 1.4)$, 形態および辺緑の認識に は，広いラチチュード（ $\mathrm{L}=2.4 \sim 3.0 ）$ が適当との結論 であった。

CRの auto モードでは，収録ラチチュードは被写体， および撮影管電圧で決定される(同一撮影系の場合)。本 研究を臨床上にどうフィードバックするのか, また，収 録ラチチュードの差が, 階調処理によって補正され得る のかどうか, 今後の課題と思うれる.

演題128 CR 胸部像を CRT 上に表示し, 肺野部, 肋骨 下肺野部, 縦隔部, 椎体部のそれぞれについて, 階調処 理の GC, GA, GS を変化させた場合の識別能について検 討したものである.

質問 （座長） CR 出力フィルムと比較してどうであ つたか？

答（野沢）部分部分について画像処理を行ったので, CRT 上の方が優れていた。

現在は実際の読影には使用していない. 将来の CRT 上での読影に対する，基礎的実験である.

\section{CR-4＼cjkstart臨床応用- 2（演題番号432～437）}

千安式部（神奈川県立がんセンター放射線第一科） 本セッションは，CRによるエネルギーサブトラクシ ヨンに関するもの 3 題, 単純撮影 2 題, 血管造影 1 題の 計 6 演題である.

演題432は, 胸部の One exposure 法によるDual energy subtraction radiography（E.S.R）に関する発表 である.E.S.R は, 肺末梢に発生する腫瘤形成傾向の乏し い肺癌の検出に極めて有効であることを臨床例をもとに 報告した． E.S.R 技術は，既発表の手技を踏襲している が，臨床的価值の高いことを強調した内容であった。

質問（梅津 九大）(1)コンベ $\mathrm{S} / \mathrm{F}$ 法で描出し得な かった腫瘤が E.S.R で描出したと述べているが，コンベ の撮影条件に問題があるのではないか？ (2) E.S.Rの 利点は, 複雑な骨構造の消去にあると思うが, 肺尖部の 骨消去が不十分のように感ずるが？

答 (1)当院のコンベによる撮影は, $140 \mathrm{kV}$ である.（濃 度補償フィルタ使用）(2)被写体によって重み係数を変 